Gut, 1986, 27, S1, 40-46

\title{
Diet formulation and choice of enteral diet
}

\author{
D B A SILK
}

From the Department of Gastroenterology and Nutrition, Central Middlesex Hospital, London

Once it has been decided to provide nutritional support via the enteral route the best formulation to meet the nutritional needs of the individual patient must be selected. A large number of enteral diets are now commercially available, and Table 1 summarises the different categories available. Until recently, controversy existed as to whether enteral feeds formulated and prepared in the hospital dietetic department should be used instead of their commercially prepared counterparts: problems caused by infection have now been well documented with "home brew" diets, ${ }^{1}$ and there are now controlled data which show that the incidence of diarrhoea is higher when "home brew" rather than commercial diets are used for enteral feeding. ${ }^{2}$ Knowledge gained about the processes entailed in the physiology of nutritional absorption and subsequent metabolism both in normal and disease states continues to influence the formulation of enteral diets, and this review will outline recent advances in those areas that are influencing diet formulation.

\section{Fat absorption}

Over the past two years there have been few research findings that have actually influenced diet formulation. The importance of preventing essential fatty acid deficiency needs emphasising, particularly as it may occur when gut function is particularly impaired and long chain triglycerides are poorly assimilated. ${ }^{3}$ As previously outlined, ${ }^{4}$ medium chain triglycerides are probably not as well assimilated in the presence of bile salt deficiency, exocrine pancreatic insufficiency, and intestinal resection as many would believe, ${ }^{5}$ and at least in the cases of exocrine pancreatic insufficiency and intestinal resection pancreatic supplements will greatly enhance energy assimilation from medium chain triglycerides and reduce steatorrhoea.

\section{Carbohydrate}

The physiology of digestion and absorption of

Correspondence to: Dr D B A Silk. Department of Castroenterology anc Nutrition, Central Middlesex Hospital. Acton Lane. London NWIO) 7NS. England.

dietary carbohydrate in relation to formulation of enteral diets has been reviewed. ${ }^{7}$ Although the early chemically defined "elemental" diets administered to man contained glucose as the sole source of carbohydrate energy, ${ }^{89}$ the glucose content was soon replaced in part by sucrose, ${ }^{10}$ and later by glucose polymer mixtures derived from the hydrolysis of starch by $\alpha$-amylase. ${ }^{7}$ Although the potential carbohydrate forms used in enteral diets have been categorised," Jones et al ${ }^{12}$ characterised in detail the composition of starch hydrolysates commonly used as the carbohydrate energy source of enteral diets. Using gel permeation chromatography, they found that most consist of a very heterogenous mixture of glucose polymers-with about $50 \%$ of the glucose content being present as polymers, with less than and $50 \%$ more than 10 glucose molecules. ${ }^{12}$

Table 1 Categorisation of enteral diets

\section{Type \\ 1 Polymeric diets}

2 Predigested chemically defined elemental diets

3 Specially formulated predigested diets Cirrhosis. Portosystemic encephalopathy

Stress

4 Diets containing fibre

\section{Comment}

Whole protcin nitrogen source, for use in patients with normal or near normal gastrointestinal function

Predigested nutrients: most diets have a low fat content. for use in patients with severely impaired gastrointestinal function

Amino acid nitrogen source High concentrations branched chain amino acids, low concentrations aromatic amino acids; indications still disputed

Amino acid nitrogen source High concentrations branched chain amino acids: may contain more than $1 \mathrm{kcal} / \mathrm{ml}$ energy Indications still disputed

Concept for the future At present fibre containing polymeric diets marketed. fibre containing predigested diets may follow: indications still under investigation 
Intestinal perfusion studies performed in normal human volunteers in the absence of luminal $\alpha$ amylase activity showed differential handling of the glucose polymers by the jejunum. The higher molecular weight glucose polymers (containing $>10$ glucose molecules) were assimilated slower than the lower molecular weight glucose polymers. It seemed that the lower weight polymers could be conferring a kinetic advantage on the transport of glucose. ${ }^{12}$ This was confirmed in a further study, ${ }^{13}$ in which purified high and low molecular weight polymer fractions were perfused. Although the $\alpha$-amylase hydrolysate of the low molecular weight glucose polymer fraction $(<10$ glucose molecules) conferred the expected kinetic advantage on the transport of glucose, the high molecular weight fraction (osmolality one fifth of the starting material) was surprisingly well absorbed, even in the absence of $\alpha$-amylase. ${ }^{13}$ The authors concluded that the energy content of enteral diets could be increased at the same time as diet osmalility was lowered, by substituting the commonly used heterogenous starch hydrolysates with purified high molecular weight fractions. So far this concept been used in only one diet (Vivonex TEN, Norwich Pharmaceuticals), with a subsequent lowering of osmolality from 830 to $630 \mathrm{mosmol} / \mathrm{kg}$.

\section{Lactose}

Lactose deficiency is common in certain racial and ethnic groups, particularly Blacks, Orientals, Indians, and Jews, with an incidence as high as $60-100 \% .{ }^{14}$ On account of this it is perhaps hardly surprising that it is now considered to be commercially wise to minimise the lactose content of new enteral products. Walike and Walike ${ }^{15}$ were the first to suggest that the lactose content of blenderised formulae was one cause of diarrhoea occurring during enteral feeding. Certainly the recent study of O'Keeffe $e t$ al $^{16}$ showed that if patients with biochemically confirmed lactose malabsorption are bolus fed with enteral diets containing lactose then diarrhoea will occur with stool volumes in excess of $11 / 24$ hours. It must be said, however, that it is far from certain that it is the lactose content that causes gastrointestinal symptoms when milk is ingested by normal subjects with biochemically confirmed lactose intolerance.

Two studies failed to show that the ingestion of $480 \mathrm{ml}$ lactose containing milk by healthy normal subjects with biochemically confirmed lactose malabsorption resulted in a higher incidence of gastrointestinal side effects than when the same subjects ingested the same quantity of lactose free milk. ${ }^{17} 18$ In a recent study by Keohane et al ${ }^{19}$ enterally fed patients with biochemically confirmed lactose malabsorption did not have a higher incidence of gastrointestinal side effects when fed a lactose containing enteral diet $(20 \cdot 9 \pm 5 \cdot 3 \mathrm{~g}$ lactose/ 24 hours) compared with the effects of a lactose free formulation. What then is the explanation for the discrepancy in these findings? The answer lies in the load (concentration $\times$ rate) of lactose that is administered to lactose "intolerant" patients. Lactase, or $\beta$-galactosidase, is a brush border hyrolase whose specific activity is reduced but not absent in patients and subjects with lactose malabsorption. If 2-3 litres of diets containing lactose are infused constantly over 24 hours then the load of lactose administered per unit time is low, and symptoms, as shown by Keohane et al ${ }^{19}$ will not occur. Symptoms will develop, however, as shown by O'Keeffe $e^{\prime} a^{16}$ if high loads of lactose are administered by the bolus technique. The commercial pressures are now such that it is unlikely that any of the new enteral diets will contain appreciable quantities of lactose.

\section{Sucrose}

In patients with a very short bowel syndrome the factors that will limit uptake of glucose from glucose polymer mixtures will usually include intraluminal and brush border saccharide hydrolysis, and in a few instances when these do not limit the rate, the capacity of the membrane carrier to mediate uptake the released monosaccharide. Jejunal perfusion studies have shown that if transport of glucose from glucose polymers is saturated sugar absorption can be enhanced if disaccharide sucrose is added..$^{20}$ This is because sucrose is hydrolysed by the sucrase moiety of the hybrid brush border hydrolase sucrase-isomaltase $^{21}$ to glucose and fructose, fructose absorption then being mediated by a carrier that is different from that used during glucose uptake. $^{22}$

\section{Protein absorption}

The digestion and absorption of dietary protein in relation to the formulation of enteral diets has been recently reviewed. ${ }^{23}$ While it remains clear that patients with normal gastrointestinal function should be fed diets containing whole protein as the nitrogen source, controversy still remains as to whether the nitrogen source of enteral diets for use in patients with severely impaired gastrointestinal function should consist of free amino acids or oligopeptides, and if oligopeptides are used, what the most rational formulation should be. Intestinal perfusion studies in our laboratory have consistently shown more efficient absorption of $\alpha$-amino acid nitrogen from partial enzymic hydrolysates of whole 
protein than equivalent equimolar free amino acid mixtures. ${ }^{24}$ On the basis of these physiological studies we proposed theoretical reasons for using peptides rather than free amino acids as the nitrogen source is predigested chemically defined "elemental" diets. ${ }^{25}$ Other benefits, which include effects on osmolality, cost, and palatability, have also been discussed. ${ }^{23} 25$ I have been struck by the variability in handling of the different partial enzymic hydrolysate of whole protein studied, ${ }^{24}$ and in recent studies I investigated the influences that starter protein composition, hydrolysis method, ${ }^{26}$ and peptide chain length ${ }^{27}$ have on absorption profiles of partial enzymic hydrolysates of whole protein.

One of the most interesting observations was the finding that subtle increases in peptide chain length from 2-3 to 3-5 amino acid residues have a deleterious effect on $\alpha$-amino acid nitrogen absorption. ${ }^{28}$ If a peptide based nitrogen source is considered to be desirable, evidence now points to the fact that mixtures of dipeptides and tripeptides rather than higher peptides will result in the most efficient rates of $\alpha$-amino acid nitrogen absorption per unit length of intestine.

\section{Amino acid $v$ peptides:clinical studies}

Three recent studies ${ }^{29-31}$ compared the efficacy of Vivonex HN, whose nitrogen source is composed of free amino acids, and Criticare $\mathrm{HN}$, whose nitrogen source is composed of partially hydrolysed protein (peptides and amino acids). Smith et al ${ }^{29}$ showed higher blood urea, nitrogen, and urinary urea excretion values in patients with inflammatory bowel disease who had been fed Vivonex HN. Similarly, increased blood urea nitrogen values were also observed in patients with pancreatic insufficiency who had been both fed with diets. ${ }^{30} \mathrm{~A}$ weight gain was seen only in the patients who had been fed Criticare $\mathrm{HN} .{ }^{30}$ In malnourished patients with head and neck cancer greater weight gains, higher serum albumin concentration, and lower rises in blood urea nitrogen were seen in the patients fed Criticare $\mathrm{HN}$. $^{31}$ Contrary to some unpublished suggestions, the differences noted in these three trials do not indicate a superiority of peptides over amino acids.

The quantitative differences in the amino acid composition between the two diets are many, ${ }^{31}$ particularly with regard to glutamine, an amino acid known to stimulate directly the urea cycle. ${ }^{31}$ Ureagenesis, with subsequent increases in excretion of urinary urea nitrogen and impairment of nitrogen balance, would thus be expected to occur with Vivonex HN rather than with Criticare HN. In my unit higher urinary urea excretion values in patients who had been fed Vivonex HN compared with those fed with Clinifeed 400 , a whole protein polymeric diet were also noted. ${ }^{32}$ The question as to whether peptides have a specific advantage over free amino acids can only be answered if patients with severely impaired gastrointestinal function are fed peptide and free amino acid diets of identical amino acid composition.

\section{Vitamin and trace elements}

The mineral, trace element, and vitamin contents of enteral diets have traditionally been based on recommended dietary allowances (RDA), which are the levels judged by the various national boards and the World Health Organisation to be adequate to meet the nutritional needs of practically all healthy persons. It had already been pointed out ${ }^{33}$ that the RDA do not cover therapeutic nutritional needs, so that vitamin and trace element requirements, affected by disease or pharmaceutical preparations, may not be met in all enteral feeds. ${ }^{33}$ Vitamin requirements have been comprehensively reviewed. ${ }^{33}$ Of the trace elements, zinc has received the most attention, and two to three times the RDA has been recommended for hypermetabolic patients. ${ }^{34}$ Requirements of other trace elements for hypermetabolic patients are unknown, and deficiencies of magnesium, copper, chromium, and selenium have all been reported in patients receiving parenteral nutrition. ${ }^{35-37}$ Recently Bunker and Clayton $^{38}$ reported discrepancies between concentrations of zinc, copper, iron, and manganese in enteral diets stated by the manufacturers and those found on analysis. Several feeds even produced less than the United States' recommended daily allowance.

\section{Electrolytes}

Table 2 summarises the approximate mean quantities of water and electrolytes handled by the gut in 24 hours by normal subjects. Despite the fact that nearly 9 litres of water and in excess of $1000 \mathrm{mmol}$ sodium is ingested, secreted, and absorbed little emphasis has been placed, until recently, on water and electrolyte absorption during enteral feeding. Small intestinal disease or resection results in an increased colonic inflow of water and electrolytes. As a consequence of the large absorptive capacity of the colon, ${ }^{39}$ however, severe diarrhoea and depletion of water and electrolytes usually only occur in the presence of coexisting colonic disease or resection. It follows that the diarrhoea, which occurs in enterally fed patients with normal or near normal 
Table 2 Approximate mean quantities of water and electrolytes handled by the gut in 24 hours by normal subjects

\begin{tabular}{lcccc}
\hline & $\begin{array}{l}\text { Water } \\
(\mathrm{ml})\end{array}$ & $\begin{array}{l}\text { Sodium } \\
(\text { mmol })\end{array}$ & $\begin{array}{l}\text { Chloride } \\
(\text { mmol })\end{array}$ & $\begin{array}{l}\text { Potassium } \\
(\text { mmol })\end{array}$ \\
\hline $\begin{array}{l}\text { Input } \\
\text { Diet }\end{array}$ & 1500 & 150 & 150 & 80 \\
$\quad$ Gut secretions & 7500 & 1000 & 750 & 40 \\
$\quad \begin{array}{c}\text { Total } \\
\text { Absorption } \\
\quad \text { Small intestine }\end{array}$ & 9000 & 1150 & 900 & 120 \\
$\begin{array}{c}\text { Colon } \\
\text { Output }\end{array}$ & 7500 & 950 & 800 & 110 \\
$\quad$ Faeces & 1350 & 195 & 97 & -3 \\
\hline & 150 & 5 & 3 & 12 \\
\hline
\end{tabular}

gastrointestinal function in up to $24 \%$ of cases,${ }^{32}$ is either due to a hormonally induced colonic secretion of water and electrolytes, a hypothesis currently unsubstantiated ${ }^{40}$ or to other causes such as a synergistic action between enteral feeding and concomitant treatment with antibiotics. ${ }^{41}$ In patients with the short bowel syndrome, however, the situation is quite different. Here, large segments of small bowel are diseased or have been resected, often with coexisting colonic disease or resection. In the absence of the reserve absorptive capacity of the colon $^{39}$ it becomes imperative that fluid and electrolyte absorption from residual small gut is maximised during enteral feeding. I was disturbed to find, therefore, that a net secretion of fluid and electrolytes were observed during in vivo steady state perfusion of segments of normal jejumum with isotonic Vivonex. ${ }^{20}$ Further studies have been performed using a range of solutions containing the amino acid and glucose polymer components of Vivonex. ${ }^{42}$ Results showed that for all the nine nutrient solutions studied there was a linear correlation between initial sodium concentration and net sodium absorption, so that if the initial concentration exceeded $90 \mathrm{mmol} / \mathrm{l}$ net sodium absorption occurred, while at concentrations below this, net secretion of sodium was observed. Water absorption was linearly related to net absorption of osmotically active particles, a substantial proportion of which was accounted for by the movement of sodium and its anions. Thus jejunal sodium secretion observed during perfusion of Vivone $\mathrm{x}^{20}$ is not a unique feature of this diet, but will occur during jejunal perfusion of any low sodium containing diet. The sodium content of four widely used predigested chemically defined "elemental diets," Vivonex, Vivonex HN, Nutranel, and Flexical is $39 \cdot 2,36 \cdot 3$, $20 \cdot 1$, and $30 \cdot 1 \mathrm{mmol} / \mathrm{l}$, respectively, at recommended dilutions, values which are substantially lower than would be required to promote net sodium and water absorption. There are therefore corroborative experimental data for suggesting that the sodium concentration of the predigested diets, whose use is recommended in the early postoperative management of the short bowel syndrome, should be raised to $80-90 \mathrm{mmol} / \mathrm{l}$.

\section{Choice of enteral diet}

PATIENTS WITH NORMAL OR NEAR NORMAL GASTROINTESTINAL FUNCTION

In our experience cumulative positive nitrogen balance in enterally fed patients has not always been achieved. ${ }^{32} 4143$ Several factors are responsible for this, including an underestimate of energy and nitrogen requirements, use of starter regimens, inadvertent removal of feeding tubes ${ }^{44}$ and poor administration techniques. ${ }^{43}$ As yet there seems to be no easy answer to the problem of inadvertent removal of feeding tubes. ${ }^{44}$ In a recent study, however, we showed that the use of starter regimens reduces nutrient intake but not the incidence of gastrointestinal symptoms, so that cumulative nitrogen balance can be improved by administering undiluted polymeric diet from the outset of feeding. ${ }^{41}$ In my experience it has been rather difficult to administer routinely more than 21 feed/24 hours, ${ }^{41} 43$ but despite this cumulative positive nitrogen balance was achieved when starter regimens were abandoned in a heterogenous group of patients who had nitrogen requirements of less than $12 \mathrm{~g} / 24$ hours. A case can be made, therefore, for recommending the routine use of a polymeric diet of energy density $1 \mathrm{kcal} / \mathrm{ml}$ for non-hypermetabolic patients with normal or near normal gastrointestinal function, the composition of which would accord with recommendations outlined in Table 3. It seemed that one way of circumventing the problems that exist in achieving positive nitrogen balance in some of the non-hypermetabolic, or modestly hypermetabolic patients (nitrogen losses $10-15 \mathrm{~g} / 24$ hours) would be to use routinely a more energy dense $(1.5 \mathrm{kcal} / \mathrm{ml})$ polymeric diet containing higher concentrations of nitrogen $(9-10 \mathrm{~g} / \mathrm{l})$. By definition, the osmolality of such a diet would be higher than the $1 \mathrm{kcal} / \mathrm{ml}$ diets, but if the carbohydrate energy moiety was rationalised according to the concepts proposed by Jones et al $^{13}$ the osmolality could be lowered. Clinical trials are currently being performed in my laboratory to determine the efficacy of this approach.

For extremely hypermetabolic patients - for example, those with burns and multiple trauma normal gastrointestinal function polymeric diets are available with an energy density of $2.0 \mathrm{kcal} / \mathrm{ml}$ and nitrogen contents of up to $14 \mathrm{~g} / \mathrm{l}$. These are 
Table 3 Choice and formulation of enteral diets

\begin{tabular}{|c|c|c|c|c|}
\hline & \multicolumn{3}{|c|}{$\begin{array}{l}\text { Polymeric diets for patients with normal or near normal } \\
\text { gastrointestinal function }\end{array}$} & \multirow{3}{*}{$\begin{array}{l}\text { Predigested diets for patients } \\
\text { with severely impaired gastro- } \\
\text { intestinal function }\end{array}$} \\
\hline & \multicolumn{2}{|c|}{$\begin{array}{l}\text { Non-hypermetabolic to moderately } \\
\text { hypermetabolic }\end{array}$} & \multirow[b]{2}{*}{ Hypermetabolic } & \\
\hline & Current & Proposed & & \\
\hline Nitrogen source $(\mathrm{g} / \mathrm{l})$ & $\begin{array}{l}\text { Protein } \\
(5-7)\end{array}$ & $\begin{array}{l}\text { Protein } \\
(9-10)\end{array}$ & $\begin{array}{l}\text { Protein } \\
(11-13)\end{array}$ & $\begin{array}{l}\text { Purified low molecular weight } \\
\text { peptide mixtures } \\
(5-10)\end{array}$ \\
\hline Carbohydrate & $\begin{array}{l}\text { Glucose } \\
\text { polymers }\end{array}$ & $\begin{array}{l}\text { Glucose } \\
\text { polymers } \pm \\
\text { sucrose }\end{array}$ & $\begin{array}{l}\text { Purified glucose } \\
\text { polymers (now }>10 \\
\text { glucose molecules) } \\
\pm \text { sucrose }\end{array}$ & Glucose polymers \\
\hline Fat source & $\begin{array}{l}\text { Long chain } \\
\text { triglycerides }\end{array}$ & $\begin{array}{l}\text { Long chain } \\
\text { triglycerides }\end{array}$ & $\begin{array}{l}\text { Long chain } \\
\text { triglycerides }\end{array}$ & $\begin{array}{l}\text { Medium chain triglycerides } \\
\text { linoleic acid }\end{array}$ \\
\hline Energy (\%) & $32-36$ & $32-36$ & $34-41$ & $?$ \\
\hline $\begin{array}{l}\mathrm{Kcal} / \mathrm{ml} \\
\text { Electrolytes }(\mathrm{mmol} / \mathrm{l})\end{array}$ & $1 \cdot 0$ & $1 \cdot 5$ & $2 \cdot 0$ & $1 \cdot 0$ \\
\hline Sodium & $30-70$ & $30-70$ & $30-70$ & $70-90$ \\
\hline Potassium & $30-70$ & $30-70$ & $30-70$ & $30-70$ \\
\hline Chlorine & $30-70$ & $30-70$ & $30-70$ & $70-90$ \\
\hline Minerals (fraction RDA) & $1 \cdot 0$ & $1-1 \cdot 5$ & $1 \cdot 5-2 \cdot 0$ & $1 \cdot 0-1 \cdot 5$ \\
\hline Vitamins (fraction RDA) & $1 \cdot 0$ & $1-1 \cdot 5$ & $1 \cdot 5-2 \cdot 0$ & $1 \cdot 0-1 \cdot 5$ \\
\hline Osmolality (mosmol/kg) & $300-400$ & Up to 500 & Up to 600 & $450-650$ \\
\hline
\end{tabular}

hypertonic diets, and I have no personal experience of their use. It should be borne in mind that there may be a real risk of infusing excess carbohydrate to these patients, some of whom already have insulin resistance. Furthermore, excessive carbohydrate loads could also have a deleterious effect on respiratory function. ${ }^{45}$ Modular formulae, whereby the composition of a diet is formulated in the diet kitchen according to the needs of the individual patient, have been proposed for these difficult patients. ${ }^{46}$

\section{PATIENTS WITH IMPAIRED GASTROINTESTINAL} FUNCTION

In cases in which the rate of nutrient absorption is limited by impaired luminal hydrolysis, or reductions in mucosal absorption, or hydrolytic capacity the use of enteral diets containing predigested nutrients will result in more efficient nutrient repletion than the use of polymeric diets discussed above. Strictly speaking, the criteria for using the predigested or so called chemically defined elemental diets will usually occur only in patients with severe exocrine pancreatic insufficiency and those with an inadequate or short bowel syndrome. Although other indications for using predigested chemically defined elemental diets have been proposed, ${ }^{47}$ there is very little controlled evidence to support most of the claims. ${ }^{48}$
When nutrient assimilation is severely impaired there are theoretical reasons for believing that nutrients should be presented to the mucosa so that maximal absorption will occur in normal subjects. Table 3 summarises the suggested formulation of such a diet, and it is based on discussions of the physiology of nutrient absorption outlined at the beginning of this paper.

In practical terms, it may often be difficult to decide whether a polymeric or predigested diet should be used. In my opinion, the assimilatory capacity of the human gastrointestinal tract for nutrients is often underestimated. For example, there is no evidence that there is any clinically important impairment of exocrine pancreatic secretion or intestinal absorptive capacity in the postoperative period. Moreover, there is no clinical evidence to support a contention that the use of predigested diets in jejunostomy feeding results in more efficient nutrient repletion than that obtained by polymeric diets.

Little attention has been directed towards enteral feeding in patients with cholestatic jaundice. In the absence of other coexisting gastrointestinal disease these patients will be able to assimilate all the major classes of nutrients except fat and fat soluble vitamins. Diets for those patients should not contain long chain triglycerides, so most of the currently available diets are not indicated. A modular formula 
based on whole protein, glucose polymers, medium chain triglycerides, linoleic acid (in the hope of preventing essential fatty acid deficiency), electrolytes, minerals, and water and fat soluble vitamins would be most appropriate. Assimilation of medium chain triglyceride by the jaundiced patient will depend on several factors, including the degree of jaundice, and the presence of coexisting gastrointestinal pathology. Although there are no data to support it, medium chain triglyicerides should probably not contribute to more than $20 \%$ of the total energy content of these formulations.

\section{CHRONIC PORTAL-SYSTEMIC ENCEPHALOPATHY}

Patients with chronic portal-systemic encephalopathy are faced with a nutritional dilemma. They require dietary protein to maintain nitrogen balance, but the ingestion of protein often precipitates encephalopathy. Despite treatment with lactulose or antibiotics many patients with cirrhosis are unable to tolerate sufficient protein to prevent long standing negative nitrogen balance. As the plasma amino acid profiles of these patients are characterised by decreased values of branched chain amino acids and increased values of aromatic amino acids (phenylalanine, tyrosine, free tryptophan and methionine), ${ }^{49}$ investigators have administered mixtures of amino acids rich in branched chain amino acids and deficient in aromatic amino acids. ${ }^{50}$ Overall, it has not been easy to draw conclusions from the published data as the controlled trials evaluated different types and degrees of encephalopathy using different mixtures of branched chain amino acids administered in different ways, different end points, and they found different results. As far as enteral nutrition is concerned, one trial ${ }^{51}$ clearly shows that a branched chain amino acid enriched enteral diet low in aromatic amino acids induced positive nitrogen balance in protein intolerant cirrhotic patients, all of whom had had chronic portal-systemic encephalopathy, to about the same degree as an equivalent amount of dietary protein without inducing encephalopathy as often. ${ }^{52}$

\section{RESPIRATORY AND CARDIAC FAILURE}

In one study respiratory, cardiovascular, and metabolic changes were monitored during balance studies in undernourished patients receiving continuous enteral feeding. ${ }^{45}$ At increasing energy infusion rates oxygen consumption, carbon dioxide production and minute ventilation, heat production, heat release and heart rate increased on both a high carbohydrate and high fat diet. Rather disturbingly, increases in carbon dioxide production and minute ventilation were greater for the high carbohydrate relative to the high fat formula. In the clinical setting care must be taken not to precipitate heart failure during continuous enteral feeding in compromised patients. Furthermore, these findings also suggest that the carbohydrate to fat ratio should be decreased in enteral diets administered to patients with respiratory failure. A new diet (Pulmocare, Ross) has been formulated along these lines.

\section{References}

1 Casewell MW. Nasogastric feeds as a source of Klebsiella infection for intensive care patients. Research and Clinical Forums 1979; 1: 101-5.

2 Keighley MRB, Mogg B, Beatley S, Allan C. 'Home brew' compared with commercial preparations for enteral feeding. Br Med J 1982; 1: 163.

3 Dodge JA, Yassa JG. Essential fatty acid deficiency after prolonged treatment with elemental diet. Lancet 1980; ii: $1256-7$.

4 Silk DBA. Future directions in supplemented nutrition. In: Lawson D, ed. Cystic fibrosis horizons. Chichester: John Wiley and Sons, 1984: 99-114.

5 Hashim SA. Medium chain triglycerides: clinical and metabolic aspects. J Am Diet Assoc 1967; 57: 221-7.

6 Forstner G, Gall G, Corey M, et al. In: Proceedings of the 8th international congress of cystic fibrosis. Toronto: Canadian Cystic Fibrosis Foundation, 1980: 137-8.

7 Moran JR, Greene HL. In: Rombeau JL, Caldwell MD, eds. Digestions and absorption in enteral and tube feeding. Philadelphia: WB Saunders, 1984: 20-43.

8 Greenstein JP, Otey MC, Birnbaum SM, et al. Quantitative nutritional studies with water soluble, chemically defined diets. X Formulation of a nutritionally complete diet. JNCI 1960; 24: 211-19.

9 Winitz M, Seedman DA, Graff J. Studies in metabolic nutrition employing chemically defined diets. I. Extended feeding of normal human adult males. Am J Clin Nutr 1970; 23: 525-45.

10 Randall HT. Enteral nutrition. Tube feeding in acute and chronic illness. JPEN 1984; 8: 113-36.

11 MacBurney MM, Young LS. Formulas. In: Rombeau $\mathrm{JL}$, Caldwell MD, eds. Enteral and tube feeding Philadelphia: WB Saunders, 1984: 171-98.

12 Jones BJM, Brown BE, Loran JS, Edgerton D, Kennedy JF, Stead JA, Silk DBA. Glucose absorption from starch hydrolysates in the human jejunum. Gut 1984; 24: 1152-60.

13 Jones BJM, Brown BE, Spiller RC, Silk DBA. Energy dense enteral feeds-The use of high molecular weight glucose polymers. JPEN 1981; 5: 567.

14 Neale G. The diagnosis, incidence and significance of disacharidase deficiency in adults. Proceedings of the Royal Society of Medicine 1968; 61: 1099-117.

15 Walike BC, Walike JW. Relative lactose intolerance: a clinical survey of tube-fed patients. JAMA 1977; 238: 948-51.

16 O'Keefe SJD, Adam JK, Cakata E, Epstein S. Nutritional support of malnourished lactose intolerant African patients. Gut 1984; 25: 942-7.

17 Haverberg L, Kwon PH, Scrimshaw NS. Comparative 
tolerance of adolescents of differing ethnic backgrounds to lactose containing and lactose free dairy drinks. I. Initial experience with a double-blind procedure. Am J Clin Nutr 1980; 33: 17-21.

18 Kwon PH, Rorick MH, Scrimshaw NS. Comparative tolerance of adolescents of differing ethnic backgrounds to lactose containing and lactose free dairy drinks. II. Improvement of a double blind test. Am J Clin Nutr 1980; 33: 22-6.

19 Keohane PP, Attrill H, Jones BJM, Brown B. Frost P, Silk DBA. Influence of lactose and Clostridium difficile in the pathogenesis of enteral feeding associated diarrhoea. Clin Nutr 1983; 1: 259-63.

20 Jones BJM, Brown BE, Silk DBA. Isotonic vivonex causes water secretion in normal human jejunum. Gut 1980; 21: 920 .

21 Conklin KA, Yamashiro KM, Gray GM. IIuman intestinal sucraseisomaltase: identification of free sucrase and isomaltase and cleavage of the hybrid into active distinct subunits. $J$ Biol Chem 1975; 250: 5735-41.

22 Milla PJ, Oyesiku JEJ, Muller DPR, Harries JP. Fructose absorption and the effects of other monosaccharides on its absorption in the rat jejunum in vivo. Gut 1977; 18: 425.

23 Keohane PP, Silk DBA. Peptides and free amino acids. In: Rombeau JL, Caldwell MD, eds. Enteral and tube feeding. Philadelphia: WB Saunders Co, 1984: 44-59.

24 Silk DBA, Fairclough PD, Clark ML et al. Uses of a peptide rather than free amino acid nitrogen source in chemically defined elemental diets. JPEN 1980; 4: 548-53.

25 Silk DBA. Nutritional support in hospital practice Oxford: Blackwell Scientific Publications, 1983: 68-99.

26 Keohane PP, Brown BE, Grimble GK, Silk DBA. The peptide nitrogen source of elemental diets comparisons of absorptive properties of five partial enzymic hydrolysates of whole protein. JPEN 1981; 5: 568.

27 Keohane P, Grimble G, Brown B, Kaminski MV, Silk DBA. Influence of peptide chain length on absorption from protein hydrolysates in man. JPEN 1982; 6: 578 .

28 Rees RG, Grimble GK, Keohane PP, et al. Peptide chain length of protein hydrolysates influences jejunal nitrogen absorption. Gut 1984; 25: 547.

29 Smith JL, Arteaga C, Heymsfield SB. Increased ureagenisis and impaired nitrogen use during infusion of a synthetic amino acid formula, a controlled trial. $N$ Engl J Med 1982; 306: 1013-18.

30 Nasrallah SM, Martin DM. Comparative effects of Criticare $\mathrm{HN}$ and Vivonex $\mathrm{HN}$ in the treatment of malnutrition due to pancreatic insufficiency. $\mathrm{Am} \mathrm{J} \mathrm{Clin}$ Nutr 1984; 39: 251-4.

31 Megvid MM, Landel AM, Terz JJ, Akrabawi SS. Effect of elemental diet on albumin and urea synthesis: comparison with partially hydrolysed protein diet. J Surg Res 1984; 37: 16-24.

32 Jones BJM, Lees R, Andrews J, Frost P, Silk DBA. Comparison of an elemental and polymeric enteral diet in patients with normal gastrointestinal function. Gut 1983; 24: 78-84.

33 Caldwell MD, Caldwell CK. Micronutrients and enteral nutrition. In: Rombeau JL, Caldwell MD, eds.
Enteral and tube feeding. Philadelphia: WB Saunders Co, 1984: 84-126.

34 Molnar SA, Bell SJ, Goodenough RD, Burke JF. Enteral nutrition in patients with burns or trauma. In: Rombeau JL, Caldwell MD, eds. Philadelphia: WB Saunders Co, 1984: 412-33.

35 Kay RG, Tasman-Jones CD, Pybus J, et al. A syndrome of acute zinc deficiency during total parenteral alimentation in man. Ann Surg 1976; 183: 331-40.

36 Van RJ, Thomson CD, McKenzie JM, Robinson MF. Selenium deficiency in total parental nutrition. Am J Clin Nutr 1979; 32: 2076-85.

37 Freeman JB, Whittine MF. Magnesium requirements are increased during total parenteral nutrition. Surgical Forum 1977; 28: 61-2.

38 Bunker VW, Clayton BE. Trace element content of commercial enteral feeds. Lancet 1983; ii: 426-28.

39 Phillips SF, Giller J. The contribution of the colon to electrolyte and water conservation in man. J Lab Clin Med 1973; 81: 733-46.

40 Brown BE, Silk DBA. Influences of duodenal Vivonex and Ensure infusion on ileal and colonic water electrolyte absorption. JPEN 1982; 6: 321 .

41 Keohane PP, Attrill H, Love M, Frost P, Silk DBA. Relation between osmolality of diet and gastrointestinal side effects in enteral nutrition. Br Med $J$ 1984; 288: $678-81$.

42 Spiller RC, Jones BJM, Silk DBA. Influence of sodium content of enteric diets on water absorption from the human jejunum. JPEN 1982; 6: 342.

43 Keohane PP, Attrill H, Love M, Frost P, Silk DBA. A controlled trial of aseptic enteral diet preparation significant effects on bacterial contamination and nitrogen balance. Clin Nutr 1983; 2: 119-22.

44 Keohane PP, Attrill H, Jones BJM, Silk DBA. Limitations and drawbacks of 'fine bore' nasogastric feeding tubes. Clin Nutr 1983; 2: 85-6.

45 Heymsfield SB, Head A, McManus CB, Seitz S, Station GW, Grossman GD. Respiratory, cardiovascular and metabolic effects of enteral hyperalimentation: influence of formula dose and composition. Am J Clin Nutr 1984; 40: 116-30.

46 MacBurney MM, Jacobs DO, Apelgren $\mathrm{KN}$ et al. Modular feeding. In: Rombeau JL, Caldwell MD, eds. Enteral and tube feeding. Philadelphia: WB Saunders Co, 1984: 199-211.

47 Russell RI. Elemental diets. Gut 1975; 16: 68-79.

48 Koretz RL, Meyer JH. Elemental diets-Facts and fantasies. Gastroenterology 1980; 78: 393-410.

49 Morgan MY, Milson JP, Sherlock S. Plasma ratio of valine, leucine and isoleucine to phenylalanine and tryosine in liver disease. Gut 1978; 19: 1068-73.

50 Walser $M$. Therapeutic aspects of branched-chain amino and keto acids. Clin Sci 1984; 66: 1-15.

51 Horst D, Grace ND, Conn HD, et al. Comparison of dietary protein with an oral branched chain - enriched amino acid supplement in chronic portal-systemic encephalopathy: a randomised controlled trial. Hepatology 1984; 4: 279-87.

52 Silk DBA. Branched chain amino acids in liver disease: Fact or Fantasy? Gut 1986; 27 (Suppl): 103-10. 